\title{
Pengembangan Modul Pembelajaran IPA dengan Tema "Pencemaran Lingkungan" untuk Meningkatkan Hasil Belajar Siswa SMP Kelas VII
}

\author{
Hani Irawati \\ Progam Studi Pendidikan Biologi, FKIP, Universitas Ahmad Dahlan \\ Kampus III, J1. Prof. Dr. Soepomo, SH, Yogyakarta, 55164 Indonesia \\ surat elektronik: hani.irawati1986@gmail.com
}

\begin{abstract}
ABSTRAK
Penelitian ini bertujuan untuk mengembangkan modul pembelajaran IPA dengan tema pencemaran lingkungan yang layak digunakan untuk meningkatkan hasil belajar siswa SMP kelas VII.

Penelitian ini merupakan Research and Development (R\&D). Pengembangan dilakukan dengan mengacu pada model 4-D yang dimodifikasi menjadi 3-D. Tahapan model 3-D meliputi define (pendefinisian), design (perancangan), dan develop (pengembangan). Penilaian produk dilakukan oleh seorang ahli materi, seorang ahli media, dua orang guru IPA, dan tiga orang teman sejawat. Uji coba dilakukan kepada 43 siswa kelas VII SMP Muhammadiyah I Wonosobo dengan rincian: IO siswa untuk uji coba kelompok kecil dan 33 siswa untuk uji lapangan. Pengumpulan data dilakukan dengan menggunakan kuesioner, tes (pretest dan posttest), dan lembar observasi. Data yang diperoleh dari kuesioner dan lembar observasi dianalisis secara deskriptif. Data pretest dan posttes dianalisis menggunakan normalized gain score yang kemudian dianalisis secara deskriptif.

Hasil penelitian adalah sebagai berikut. I) Modul pembelajaran IPA dengan tema "Pencemaran Lingkungan" dinilai dari: (a) aspek kelayakan isi berkualitas baik menurut ahli materi, dan berkualiatas sangat baik menurut guru dan teman sejawat; (b) aspek bahasa dan gambar berkualitas baik menurut ahli materi, dan berkualiatas sangat baik menurut guru dan teman sejawat; (c) aspek penyajian berkualitas sangat baik menurut ahli media, guru, dan teman sejawat; dan (d) aspek kegrafikan berkualiatas sangat baik menurut ahli media, guru, dan teman sejawat. 2) Tanggapan siswa terhadap modul yang dikembangkan berkualitas sangat baik dari aspek materi, bahasa dan gambar, penyajian, dan tampilan. 3) Peningkatan hasil belajar dengan menggunakan modul yang dikembangkan berkategori sedang dengan rerata gain score sebesar 0,50. 4) Terjadi peningkatan 62,09 \% jumlah siswa yang mencapai ketuntasan belajar. Hasil tersebut menunjukkan bahwa modul pembelajaran IPA dengan tema "Pencemaran Lingkungan" hasil pengembangan layak digunakan untuk meningkatkan hasil belajar siswa SMP kelas VII.
\end{abstract}

Kata kunci: modul, IPA, pencemaran lingkungan, hasil belajat

\section{Pendahuluan}

Pembelajaran IPA di SMP/MTs harus diberikan secara terpadu sesuai dengan amanat kurikulum. Dalam pembelajaran IPA, suatu konsep atau tema dibahas dari berbagai aspek bidang kajian yaitu dari kajian fisika, kimia, dan biologi. Misalnya materi tentang lingkungan bisa dapat dibahas dari sudut pandang makhluk hidup dan proses kehidupan (biologi), energy dan perubahannya (fisika), serta materi dan sifatnya (kimia). Dengan demikian melalui pembelajaran terpadu beberapa konsep yang relevan untuk dijadikan tema tidak perlu dibahas berulang kali dalam bidang kajian yang berbeda.
Pembelajaran IPA ternyata pelaksanaannya di sebagian besar sekolah masih dilakukan secara terpisah. Pencapaian kompetensi dasar mata pelajaran masih dilakukan sesuai dengan bidang kajianmasing-masing. IPA masih terpecah-pecah dalam kompetensi dasar biologi, kimia, dan fisika, tanpa ada keterpaduan di dalamnya. Pembelajaran IPA yang masih parsial juga terjadi di SMP Muhammadiyah I Wonosobo. Latar belakang pendidikan guru IPA yang berasal dari disiplin ilmu biologi, kimia, dan fisika menyebabkan guru mengalami kesulitan untuk memadukan pembelajaran IPA. Bahan ajar yang digunakan di SMP Muhammadiyah I Wonosobo berupa buku teks IPA Terpadu, namun ternyata buku yang digunakan belum 
berbasis terpadu. Kendala-kendala yang dihadapi dalam pembelajaran IPA menjadikan hasil belajar IPA khususnya di kelas VII kurang maksimal.

Guru memerlukan suatu contoh bahan ajar untuk pembelajaran IPA yang terpadu, dan salah satu alternative bahan ajar yang dapat dikembangkan oleh guru adalah modul. Melalui modul guru dapat memadukan beberapa kompetensi dasar menjadi sebuah tema. Tema yang dipilih oleh guru dapat disesuaikan dengan perkembangan kognitif siswa dan disesuaikan dengan lingkungan sekitar siswa. Pengorganisasian materi yang baik dalam modul diharapkan dapat membantu siswa untk memahami materi dengan lebih baik, sehingga diharapkan siswa mampu mencapai ketuntasan belajar.

Berdasarkan uraian di atas, maka penulis terdorong untuk mengembangkan modul pembelajaran IPA untuk siswa SMP kelas VII dengan tema pencemaran lingkungan. Modul yang dikembangkan merupakan modul cetak dan tema pencemaran lingkungan dipilih karena tema tersebut sangat dekat dengan kehidupan siswa. Pencemaran lingkungan banyak terjadi di Wonosobo mulai dari pencemaran tanah akibat sampah dan pestisida yang digunakan untuk penyemprotan sayuran, pencemaran udara akibat kendaraan bermotor, dan juga pencemaran air akibat sampah rumah tangga.

Rumusan masalah dalam penelitian ini adalah: (I)bagimana kelayakan modul yang dikembangkan, (2)bagaimana respon siswa setelah pembelajaran menggunkan modul yang dikembangkan, (3)apakah modul yang dikembangkan dapat meningkatkan hasil belajar siswa.

Tujuan Penelitian pengembangan ini adalah: (I) mengembangkan modul pembelajaran IPA dengan tema pencemaran lingkungan (2)mengetahui kelayakan modul IPA dengan tema pencemaran lingkungan (3) mendeskripsikan respon siswa selama pembelajaran menggunakan modul (4) Mengetahui peningkatan hasil belajar siswa setelah menggunakan modul pembelajaran yang dikembangkan.

\section{Metode Penelitian}

Penelitian ini merupakan penelitian pengembangan dengan menggunakan model pengembangan 4-D yang dikembangkan oleh Thiagarajan, Semmel dan Semmel (1974: 5). Pada penelitian ini model 4-D dimodifikasi menjadi 3-D yang terdiri dari define, design, develop. Pada tahap pendefinisian (define) terdiri atas tahap pra penelitian, analisis siswa, analisis kurikulum, analisis materi, dan analisis tujuan pembelajaran. Tahap perancangan (design) terdiri atas pemilihan format dan design awal modul, sedangkan tahap pengembangan (develop) terdiri atas validasi perangkat diikuti revisi dan uji coba kepada siswa.

Desain uji coba dibagi menjadi dua tahap, tahap satu valiadasi oleh subjek perorangan dan tahap kedua uji coba pada kelompok kecil dan uji lapangan. Subjek penilaian terbagi menjadi tiga kelompok yaitu reviewer internal, reviewer eksternal, dan siswa untuk uji coba. Reviewer internal terdiri atas ahli materi dan ahli media serta teman sejawat. Reviewer eksternal terdiri atas guru IPA. Uji coba kelompok kecil dilakukan terhadap IO siswa yang memiliki kualifikasi rata-rata nilai ulangan harian IPA tertinggi, terendah, dan sedang di kelas VII dan uji lapanagan dilakukan kepada 33 siswa kelas VII B SMP Muhammadiyah I Wonosobo. Data yang diperoleh terdiri atas data primer berupa data penilaian dari ahli, guru, dan teman sejawat. Data meliputi skor penilaian dari aspek kelayakan isi, aspek bahasa dan gambar, aspek penyajian, serta aspek kegrafisan. Data sekunder dari hasil kegiatan pembelajaran meliputi jumlah sisiwa yang telah mencapai ketuntasan belajar dan peningkatan hasil belajar siswa.

Analisis data dilakukan terhadap kelayakan modul dan respon siswa dengan cara melakukan tabulasi data yang diperoleh setiap komponen, sub-komponen dari butir penilaian dan menghitung skor rata-rata dari setiap komponen dengan menggunakan rumus:

$$
\begin{aligned}
& \bar{X}=\frac{\sum X}{n} \\
& \text { Keterangan: } \\
& \bar{X} \quad=\text { skor rata-rata } \\
& \sum X=\text { jumlah skor } \\
& n \quad=\text { jumlah penilain }
\end{aligned}
$$

(direktorat pembinaan SMA, 2010: 60)

Skor yang telah diperoleh dan ditabulasi kemudian dirata-rata dan diubah menjadi nilai berkategori.

Tabel I.

Konversi skor penilaian ideal

\begin{tabular}{cccc}
\hline No & Rentang skor (i) & Nilai & Kategori \\
\hline 1 & $\mathrm{Mi}+1,5 \mathrm{SDi} \leq \mathrm{x} \leq \mathrm{Mi}+3,0 \mathrm{SDi}$ & $\mathrm{A}$ & $\begin{array}{c}\text { Sangat } \\
\text { Baik }\end{array}$ \\
\hline 2 & $\mathrm{Mi}+0 \mathrm{SDi} \leq \mathrm{x}<\mathrm{Mi}+1,5 \mathrm{SDi}$ & $\mathrm{B}$ & Baik \\
\hline 3 & $\mathrm{Mi}-1,5 \mathrm{SDi} \leq \mathrm{x}<\mathrm{Mi}+0 \mathrm{SDi}$ & $\mathrm{C}$ & Kurang \\
\hline 4 & $\mathrm{Mi}-3 \mathrm{SDi} \leq \mathrm{x}<\mathrm{Mi}-1,5 \mathrm{SDi}$ & $\mathrm{D}$ & $\begin{array}{c}\text { Sangat } \\
\text { Kurang }\end{array}$ \\
\hline
\end{tabular}

Keterangan :

$\mathrm{Mi} \quad$ : mean ideal

SDi : standar deviasi ideal

$\mathrm{Mi} \quad=1 / 2($ skor maks ideal + skor min ideal $)$

SDi $=(\mathrm{I} / 2)(\mathrm{I} / 3)($ skor maks ideal - skor min ideal)

Skor maks ideal $=\sum$ butir kriteria $\times$ skor tertinggi

Skor min ideal $=\sum$ butir kriteria $\times$ skor terendah

Modul yang dikembangkan dapat digunakan apabila penilaian dari para ahli berkategori baik. Untuk mengetahui peningkatan hasil belajar siswa digunakan teknil normalized gain score (Hake, 2002: 3).

Keterangan:

$$
<g>=\frac{\% \text { postcore }-\% \text { prescore }}{100-\% \text { prescore }}
$$

$$
\begin{array}{ll}
<\mathrm{g}> & \text { : nilai normalize gain } \\
\% \text { Postcore } & \text { : persentase nilai post-test } \\
\% \text { Prescore } & \text { : persentase nilai pre-test }
\end{array}
$$


Tabel 2

Kriteria indeks gain

\begin{tabular}{cc}
\hline Indeks $<\mathrm{g}>$ & Kriteria \\
\hline$(<\mathrm{g}>)>0,70$ & Tinggi \\
\hline $0,30<(<\mathrm{g}>)<0,70$ & Sedang \\
\hline$(<\mathrm{g}>) \leq 0,30$ & Rendah \\
\hline
\end{tabular}

Teknik analisis ketuntasan atau ketercapaian pembelajaran siswa diperoleh dengan menggunakan rumus yang dibuat oleh Ground dan Lin (Purwanto, 2008: 207) berikut ini:

Ketuntasan individu $=\frac{\text { Skor yang diperoleh siswa }}{\text { Skor maksimal }} \times 100$

Berdasarkan ketetapan ketuntasan belajar yang ditetapkan oleh SMP Muhammadiyah I Wonosobo, siswa dinyatakan tuntas hasil belajarnya (ketuntasan individu) apabila telah mencapai nilai 72 sebagai batas minimum penguasaan materi.

\section{Hasil dan Pembahasan}

\section{Hasil Pengembangan Modul Pembelajaran}

Penelitian pengembangan yang dilakukan menggunakan model 3-D yang dimodifikasi dari model 4-D. Pada tahap pertama yaitu define (Pendefinisian) tujuannya adalah untuk menetapkan dan mendefinisikan kebutuhan-kebutuhan di dalam proses pembelajaran. Ada lima langkah-langkah pokok dalam penelitian ini, yaitu: pra penelitian, analisis siswa, analisis kurikulum, analisis materi, dan perumusan tujuan pembelajaran.

Tahap kedua design (perancangan) terdiri dari pemilihan format modul dan desain awal modul. Format modul yang dikembangkan disesuaikan dengan kriteria buku teks yang dikeluarkan oleh BSNP. Adapun format dari modul ini terdiri atas empat komponen utama yaitu: isi, kebahasaan, penyajian, dan kegrafikaan. Pada tahap desain awal modul tema yang dipilih adalah "pencemaran lingkungan” dengan sub-sub tema meliputi: pencemaran lingkungan dan bahan kimia rumah tangga. Modul pembelajaran yang dikembangkan terbagi dalam dua kegiatan belajar, yaitu kegiatan belajar I (pencemaran lingkungan) dan kegiatan belajar 2 (bahan kimia rumah tangga).

Tahap ketiga yang dilakukan adalah tahap develop (pengembangan), dalam penelitian ini meliputi hasil uji coba ahli, uji coba kelompok kecil, dan uji coba lapangan. Uji coba ahli dilakukan untuk mengevaluasi modul pembelajaran IPA yang dikembangakan yaitu berupa penilaian dan saran maupun masukan. Uji coba ahli dibagi menjadi dua bagian yaitu reviewer internal dan reviewer eksternal. Reviewer internal terdiri dari ahli materi, ahli media, dan teman sejawat. Reviewer eksternal terdiri dari dua orang guru IPA. Setelah evaluasi dari ahli materi, ahli media, guru IPA, dan teman sejawat dilakukan, penilaian dan masukan yang diperoleh dari para ahli, guru IPA, dan teman sejawat tersebut dijadikan sebagai pedoman untuk merevisi produk awal modul. Setelah produk awal direvisi, selanjutnya diuji cobakan pada siswa pada uji coba kelompok kecil. Uji coba kelompok kecil dilakukan di SMP Muhammadiyah I Wonosobo, dengan objek siswa yang dipilih secara acak yaitu 3 siswa dari kelas VII A, 3 siswa dari kelas VII C dan 4 siswa dari kelas VII D. Setelah dilakukan uji coba kelompok kecil, produk direvisi kembali, berdasarkan kelemahan-kelemahan yang ditemukan saat uji coba kelompok kecil. Setelah direvisi kembali, produk selanjutnya diuji cobakan pada siswa sebagai uji lapangan, yaitu uji coba pada kelas sesungguhnya.

\section{Hasil Evaluasi Produk}

Modul pembelajaran yang dikembangkan dinilai oleh ahli materi, ahli media, guru IPA dan juga teman sejawat. Ahli materi memberikan penilaian pada aspek kelayakan isi dan aspek bahasa dan gambar. Rerata penilaian dari ahli materi dapat dilihat pada Tabel 3 .

Tabel 3. Data hasil penilaian ahli materi

\begin{tabular}{lcc}
\hline \multicolumn{1}{c}{ Aspek } & Skor total & Kategori \\
\hline Kelayakan isi & 32,00 & Baik \\
\hline Bahasa dan gambar & 24,00 & Baik \\
\hline
\end{tabular}

Menurut ahli materi sebagian besar materi dalam modul sudah berhubungan dengan lingkungan dan kehidupan sehari-hari siswa. Ahli materi memberikan masukan pada aspek bahasa dan gambar terutama pada warna modul yang kurang kontras dan ketidak seragaman font tulisan. Selain itu, ahli materi juga memberikan masukan untuk referensi gambar-gambar yang digunakan dalam modul. Masukan dari ahli materi digunakan untuk merevisi modul draf I dan perbaikannya menghasilkan modul draf II.

Ahli media memberikan penilaian terhadap modul yang dikembangkan pada aspek penyajian dan aspek kegrafikaan. Rerata penilaian dari ahli media dapat dilihat pada tabel 4.

Tabel 4. Data hasil penilaian ahli media

\begin{tabular}{lcc}
\hline \multicolumn{1}{c}{ Aspek } & Skor total & Kategori \\
\hline Penyajian & 57,00 & Sangat baik \\
\hline Kegrafikaan & 24,00 & Sangat baik \\
\hline
\end{tabular}

Ahli media memberikan penilaian sangat baik terhadap aspek penyajian, namun ada sedikit kekurangan dalam modul antara lain penyajian modul belum dapat memaksimalkan siswa untuk berfikir inovatif, selain itu juga siswa belum maksimal untuk memecahkan masalah dan mengambil keputusan.

Guru IPA memberikan penilaian terhadap modul yang dikembangkan pada aspek kelayakan isi, bahasa dan gambar. penyajian, serta kegrafikaan. Adapun penilaian dari guru IPA dapat dilihat pada Tabel 5. 
Tabel 5. Data hasil penilaian guru IPA

\begin{tabular}{lcc}
\hline \multicolumn{1}{c}{ Aspek } & Skor Total & Kategori \\
\hline Kelayakan isi & 35,00 & Sangat Baik \\
\hline Bahasa dan Gambar & 29,50 & Sangat baik \\
\hline Penyajian & 59,00 & Sangat baik \\
\hline Kegrafikaan & 23,00 & Sangat baik \\
\hline
\end{tabular}

Dari aspek kelakayan isi guru IPA memberikan penilaian sangat baik, namun ada beberapa bagian yang harus diperbaiki terutama mengenai kesesuaian contoh yang digunakan dengan materi pembelajaran. Menurut guru IPA contoh yang diberikan dalam modul sudah relevan dengan materi pembelajaran, tetapi masih sulit dipahami oleh siswa. Dari aspek kegrafikaan guru IPA memberikan penilaian bahwa warna gambar yang digunakan sudah sesuai dengan pesan yang ingin disampaikan tetapi belum mampu menimbulkan minat baca siswa.

Tabel 6. Data hasil penilaian teman sejawat

\begin{tabular}{lcc}
\hline \multicolumn{1}{c}{ Aspek } & Skor Total & Kategori \\
\hline Kelayakan isi & 40,00 & Sangat baik \\
\hline Bahasa dan gambar & 28,67 & Sangat baik \\
\hline Penyajian & 52,67 & Sangat baik \\
\hline Kegrafikaan & 23,00 & Sangat baik \\
\hline
\end{tabular}

Pada aspek bahasa dan gambar teman sejawat memberikan masukan untuk penyempurnaan modul, salah satunya adalah dengan memberikan gambargambar kartun yang berisi pertanyaan-pertanyaan agar siswa lebih tertarik. Menurut teman sejawat kekurangan modul yang dikembangkan dari aspek penyajian adalah kurang mampu memotivasi siswa untuk berpikir secara kreatif dan inovatif. Menurut teman sejawat kekurangan yang ada dalam modul pembelajaran pada aspek kegrafikaan adalah pada kesesuaian proporsi gambar dan bahasa paparan. Bahasa dan gambar yang digunakan menurut teman sejawat sudah cukup baik, namun pesan yang ingin disampaikan masih kurang.

Tabel 7. Data hasil tanggapan siswa terhadap modul pembelajaran IPA

\begin{tabular}{lcc}
\hline \multicolumn{1}{c}{ Aspek } & Skor total & Kategori \\
\hline Materi & $\mathrm{I} 4,82$ & Sangat baik \\
\hline Bahasa dan gambar & 22,39 & Sangat baik \\
\hline Penyajian & 44,73 & Sangat baik \\
\hline Tampilan & $\mathrm{I} 8,48$ & Sangat baik \\
\hline
\end{tabular}

Tanggapan siswa terhadap modul yang dikembangkan berkategori sangat baik untuk semua aspek.

\section{Hasil belajar siswa}

Sebelum pelaksanaan proses pembelajaran dilaksanakan terlebih dahulu pretest dan setelah proses pembelajaran selesai siswa diberikan posttest. Pemberian pretest bertujuan untuk mengukur pemahaman awal siswa terhadap materi yang akan dibahas, sedangkan posttest bertujuan untuk mengukur kembali sejauh mana pemahaman siswa terhadap materi yang telah dibahas. Hasil ketuntasan belajar siswa dapat dilihat pada tabel 8 .

Tabel 8. Data hasil tes prestasi belajar siswa

\begin{tabular}{ccc}
\hline Jumlah siswa & Rerata nilai pretes & $\begin{array}{c}\text { Rerata nilai } \\
\text { post test }\end{array}$ \\
\hline 33 & 47,48 & 76,96 \\
\hline
\end{tabular}

Berdasarkan data yang diperoleh dapat diketahui bahwa modul pembelajaran dengan tema Pencemaran Lingkungan dapat membantu meningkatkan rerata hasil belajar siswa SMP Muhammadiyah. Kenaikan rerata nilai posttest terhadap nilai pretest sebesar $62,89 \%$ dari rerata 47,48 menjadi 76,96. Kriteria ketuntasan minimal (KKM) untuk mata pelajaran IPA kelas VII di SMP Muhammadiyah I Wonosobo sebesar 72, apabila dilihat dari nilai KKM tersebut maka jika dipersentasikan ketuntasan belajar siswa sebesar 84,85\%.

Data peningkatan hasil belajar siswa diperoleh melaluin pretest dan posttes kemudian dianalisis menggunakan gain score. Perhitungan hasil belajar melalui gain score diperoleh rerata skor 0,55. Berdasarkan pengkategorian hasil analisis gain score maka rerata skor 0,55 berarti peningkatan hasil belajar siswa masuk dalam kategori sedang. Secara rinci peningkatan hasil belajar siswa yang masuk dalam kategori tinggi sebanyak 5 siswa, kategori sedang sebanyak 25 siswa, dan kategori rendah sebanyak 3 siswa. Peningkatan hasil belajar tersebut dapat dilihat pada tabel 9 .

Tabel 9. Perhitungan normalisasi gain score uji coba lapangan

\begin{tabular}{ccc}
\hline Jumlah siswa & Rerata $(\mathrm{g})$ & Rerata Kriteria \\
\hline 33 & 0,55 & Sedang \\
\hline
\end{tabular}

\section{Revisi Produk}

Revisi produk dilakukan berdasarkan saran dari ahli materi, ahli media, guru IPA, teman sejawat, dan temuan saat uji coba kelompok kecil maupun uji coba lapangan. Revisi tahap pertama dilakukan setelah produk awal divalidasi oleh ahli materi, ahli media, guru IPA, dan teman sejawat. Hasil validasi yang berupa penilaian, saran dan kritikan dijadikan sebagai pedoman dalam merevisi produk awal. Revisi produk awal ini menghasilkan produk yang layak untuk diujicobakan. Produk hasil uji revisi tahap pertama ini, digunakan untuk uji coba kelompok kecil. Pada revisi tahap pertama, perbaikan dilakukan yaitu pada Perbaikan pada cover modul, font tulisan, warna gambar yang kurang kontras, sumber referensi yang belum dituliskan, kotak peta konsep. dan resume yang belum runtun.

Revisi tahap kedua dilakukan setelah produk diujicobakan pada uji coba kelompok kecil. Revisi ini berdasarkan hasil kegiatan pembelajaran menggunanakan modul hasil pengembangan, observasi yang dilakukan pada uji coba kelompok kecil, serta berdasarkan 
tanggapan yang diberikan oleh siswa. Pada revisi tahap kedua, perbaikan dilakukan yaitu pada aktivitas sains I dan aktivitas sains 2 .

Revisi tahap ketiga merupakan revisi terhadap produk yang digunakan pada uji coba lapangan. Revisi ini berdasarkan hasil kegiatan pembelajaran menggunakan modul hasil pengembangan serta berdasarkan data observasi yang dilakukan pada uji coba lapangan. Pada revisi tahap ketiga, perbaikan dilakukan yaitu pada kegaiatan belajar I, dan perbaikan pada glosarium.

\section{Kajian produk akhir}

Modul pembelajaran IPA dengan tema pencemaran lingkungan telah selesai dikembangkan. Tiga tahapan penelitian yang dilalui yaitu: (I) validasi ahli, validasi guru IPA, dan validasi teman sejawat; (2) temuan uji coba kelompok kecil; (3) temuan uji coba lapangan. Hasil akhir produk pengembangan ini adalah modul pembelajaran IPA dengan tema pencemaran lingkungan untuk siswa SMP kelas VII.

Pembahasan kajian produk akhir pengembangan modul pembelajaran ini merupakan hasil konfirmasi antara kajian teori dan temuan penelitian sebelumnya, dengan hasil-hasil penelitian yang diperoleh. Pembahasan tersebut meliputi karakteristik modul pembelajaran IPA dari aspek kelayakan isi, aspek bahasa dan gambar, aspek penyajian, dan aspek kegrafikaan, serta temuan pada uji coba lapangan.

Berdasarkan penialian dari ahli, guru, dan teman sejawat semuanya memberikan penilaian dalam kategori baik dan snagat baik. Adapun temuan pada saat pelaknasanaan pembelajaran dengan menggunakan modul dapat meningkatkan hasil belajar siswa. Berdasarkan kajian tersebut dapat dikatakan bahwa modul yang dikembangkan ini merupakan produk yang sudah layak digunakan dalam kegiatan pembelajaran IPA. Kelayakan tersebut juga didukung oleh hasil penilaian aspek kelayakan isi, aspek bahasa dan gambar, aspek penyajian, serta aspek kegrafikaan dari ahli materi, ahli media, guru IPA, dan teman sejawat.

\section{Simpulan}

Berdasarkan hasil penelitian dan analisis data yang telah dilakukan maka dapat disimpulkan:

I. Penelitian yang dilakukan menghasilkan produk berupa modul pembelajaran IPA dengan tema pencemaran lingkungan yang layak digunakan untuk pembelajaran IPA bagi siswa SMP kelas VII.

2. Kualitas modul pembelajaran IPA Terpadu yang dikembangkan ditinjau dari aspek kelayakan isi, menurut ahli media berkategori "baik", sedangkan menurut guru IPA dan teman sejawat berkategori "sangat baik". Ditinjau dari aspek bahasa dan gambar, modul yang dikembangkan menurut penilaian ahli materi berkualiatas "baik", sedangkan menurut guru IPA, dan teman sejawat berkualiatas "sangat baik". Berdasarkan penilaian dari ahli media, guru IPA, dan teman sejawat, ditinjau dari aspek penyajian dan kegrafikaan modul yang dikembangkan berkategori "sangat baik".

3. Respon siswa selama pembelajaran menggunakan modul sangat baik, siswa beranggpan bahwa modul yang dikembangkan sesuai dengan karakteristik siswa SMP yang belum terbiasa dengan segala sesuatu yang abstrak dan materi dalam modul dekat dengan keseharian siswa.

4. Berdasarkan tes hasil belajar peserta didik, penerapan modul pembelajaran IPA dapat meningkatkan hasil belajar peserta didik dengan kategori sedang.

\section{Daftar Pustaka}

Direktorat Pembinaan SMA (2010). Juknis penyusunan perangkat penilaian afektif di SMA. Diambil tanggal I0 Oktober, dari

http://suadinmath.files.wordpress.com./20I I/0I/03juknis-penilaian-afektif_isi-revisi_0I04.pdf.

Hake, R.R. (1998). Interactive-Engagement vs Traditional Methods: A six Thousand-Students Survey of Mathematics Test Data for Introductory Physics Course. The American Journal of Physics Research, 66, 64-74. . (2002). Relationship of individual students normalized learning gains in mechanics with gender, highschool physics, and pretest scores on mathematics and spatial visualization. http://www.arxiv.org

Purwanto. (20I I). Evaluasi hasil belajar. Yogyakarta: Pustaka Pelajar.

Thiagarajan, S., Semmel, D.S. \& Semmel, M.I. (1974). Instructional development for training techers of exeptional children. Blomington Indiana: Indiana University. 